\title{
Sirojul Ummah: Music in Social Interaction
}

\author{
Febbry Cipta ${ }^{\bowtie}$, Sandie Gunara
}

\author{
Universitas Pendidikan Indonesia, Indonesia
}

Submitted: October 14, 2019. Revised: January 9, 2020. Accepted: November 4, 2020

\begin{abstract}
This article describes music's role in social interactions carried out by female members of the Marawis group Sirojul Ummah. The Marawis music is the medium they use in their efforts to convey Islamic knowledge and understanding, both for this group itself and for the surrounding community. The research method used is qualitative, in which data are collected from observations, interviews, and literature review, while the technique in analyzing data is done through a contextual approach. Social interaction in this study is viewed from the associative and dissociative aspects in the form of actions that include rational instrumental action, value rational action, effective action, and traditional action. Music is present in each of these actions. Music is both a subject and an object in social interaction, both in-groups, and out-groups. The associative and dissociative aspects of in-groups can be seen from how musical ideas and performances are developed and honed through practice activities. This activity is carried out because good musical performance is supported by techniques and methods of singing, playing, and presenting musical articulation, ornamentation, and harmonization. At the same time, the associative and dissociative aspects of out-groups can be seen from their activities in filling out events in society. The interaction process is built-in pleasant and informal situations which are shaped by an interest in music and family relationships. Since childhood, they have known each other; thus, they understand the characteristics of each person. Maturity, the maturity of thinking, and acting tend to avoid emotional conflicts that may occur. In this context, music is not only a medium for interaction, but can be a motivation in building these interactions.
\end{abstract}

Keywords: Marawis; music; women; social interaction

How to Cite: Cipta, F., \& Gunara, S. (2020). Sirojul Ummah: Music in Social Interaction. Harmonia: Journal of Arts Research And Education, 20(2), 153-160

\section{INTRODUCTION}

If we pay attention to the journey of spreading Islam in Indonesia, music has long been used as a medium of preaching by the ulama (scholars), even since the days of Wali Songo (Patzold, 2011). Meanwhile, when referring to the opinion of Seashore (1967), and Pradoko (2019), it is used because music has a contextual aesthetic, namely music is not limited to the form of tones and rhythms, but melody patterns and the musical accompaniment that cover language texts (lyric) becomes a medium in interpreting and interacting with others. On the other hand, Umar (2017) states that music is built by taste, which through feeling, a person can make a more effective relationship with God and fellow humans. Thus, these views can be used as a basis for researchers to understand more deeply about the activities of Sirojul Ummah in social interaction to spread and develop knowledge and understanding of monot-

\footnotetext{
Corresponding author:

E-mail: febbrycipta77@upi.edu
} 
heism and piety to the community.

The study of the role of music in social interaction is not new. Several articles related to this study have been written, including by Azoma and Nuqul (2017), Haris and Amalia (2018), Widiyanti, Wadiyo, and Sunarto (2016), and Kurniawan and Djohan (2017). However, at least this article that we write gives something different when viewed from the subject, namely the Marawis group consisting of housewives who call themselves Sirojul Ummah.

This study focuses on the problem of how the characteristics of social interaction and how the actions were taken by the Marawis group Sirojul Ummah in their process of developing aspects of articulation, ornamentation, and musical harmonization. Referring to the opinion of Zinn and Hogenson (1987), aspects of music are constructed by sound attributes, which include frequency, amplitude, timbre, and duration. Frequency is related to pitch, namely high and low tones, the amplitude is related to dynamics, namely the loudness and softness of the sound, while timbre is related to the tone color or sound color, while duration is related to time, namely fast or slow, as well as long/short sounds and mute (silent signs). Whereas when referring to Andjani (2014) it can be said that music, in addition to sound and silence, tone and rhythm, or space and time, is deeper than that; music is text and context, or object and subject. Some may argue that music is a universal and abstract language, but many people can communicate with these abstract musical languages more effectively.

Social interaction includes aspects of purpose, emotion, and behavior (Santoso, 2010). He expressed his opinion that a group consisting of individuals is formed because of the same goal, supported by the same emotional atmosphere, and the efforts made through each member's activities. On the other hand (Wulansari, 2013), apart from cooperation, social interactions can also take the form of disputes, competition, and accommodation. Cooperation can occur because of the same goal, both among individuals in a group, and among groups in a society. Each individual and each group try to interact to support and help each other and build ethical and effective communication. Meanwhile, disputes can occur when interactions turn out to result in differences of opinion and views, while conflicting people and conflicting groups have difficulty building good communication, making it difficult to determine solutions to problems.

On the other hand, competition is a form of social activity that can take social struggle. Competition can occur because there is the same motivation to get something. Still, something is limited in number so that each individual or each group must compete in achieving these goals. Meanwhile, accommodation is a condition when a dispute or conflict can be resolved to reestablish good interaction. Besides, capacity can also be in the form of activity to accommodate competition through competition concepts, with various procedures and work systems that competing parties and accommodating parties must comply with.

Gilin and Gilin (1950) in their discussion of the Dynamics of Social Organization, distinguish forms of social interaction into two characteristics of social processes that are caused by social interactions, namely associative and dissociative. Referring to (Soekanto, 2017), these associative characteristics are in the form of cooperation, accommodation, assimilation, and acculturation. Meanwhile, disputes, contradictions, and competition are included in the dissociative characteristic. The social process characteristics are based on actions regarding the goals, work steps, and results achieved by interested individuals and groups.

Social interaction is built by various relationships between individuals with one another, or it can be individual relations with groups and relationships between group and group. These relationships are carried out through actions that can affect social systems and structures. Meanwhile, according to Ritzer (2012), these actions 
can be distinguished in instrumental rationality, value rationality, affective actions, and traditional actions. The act of instrument rationality is based on the expectation of individual objects and behavior as a condition and means of achieving goals through rational efforts. Value rationality is a social action based on thoughts and efforts in which the condition and means of interaction are related to subjective and objective values, as well as ethical and aesthetic. At the same time, effective actions are social actions based on individual feelings and enthusiasm in responding to social conditions. Traditional actions are actions that interact through work steps that are considered normal because of inherent habits.

\section{METHOD}

This research is a type of qualitative research with a design described descriptively. This is done by researchers to examine more deeply various phenomena and information obtained in the field. The steps are taken and the procedures carried out during the research are more open based on the observation and interview guidelines that have been prepared. Referring to Alwasilah (2011) and Subandi (2011), this method was chosen and carried out as an effort for researchers to study various phenomena that occurred in the field, so that researchers could gain in-depth understanding and knowledge about music in social interactions in the Marawis group Sirojul Ummah. During the research process, the researchers built a good relationship with the research subjects to get a complete and comprehensive picture of how the characteristics of social interaction occur, and the social actions carried out by the members of the Marawis music group Sirojul Ummah in music, both between personnel with personnel (in-group) as well as between members of the Marawis music group Sirojul Ummah and the community (out-group).

The research data collected is the result obtained from observation, interviews, and documentation, which was carried out in the period of late August 2019 to midOctober 2019. Observations made by researchers were divided into two categories, namely direct and indirect observations. Direct observations were made when the researchers observed various things that were happening in the field, which were related to various activities of the Sirojul Ummah music group personnel, such as their involvement in music, economics, education, communication, and religion. Meanwhile, indirect observations were made when the researchers observed various documents obtained, such as video, audio, and photos of the activities of the Marawis music group Sirojul Ummah. The interviews conducted by researchers were unstructured, even though the researcher also prepared important notes as a guide in conducting interviews such as the names of personnel, the formation of the Marawis music group Sirojul Umah, practicing and performing activities, social relations among group members and with the community, education, and hobbies. To obtain data, validity, observations, and interviews were also carried out on other objects and parties that were considered relevant to this study's purpose.

The collected data were then analyzed using a contextual approach. This technique is done by researchers because at first, researchers did not know for certain about how the actual conditions that occur in the field. However, they already had the basics of knowledge about the topic of this study. The researcher's analysis process refers to the content, narrative, and discourse aspects as an effort to understand how the relationships between statements and events are. When referring to Alwasilah (2011), Budiasih (2014), and Junaid (2016), it can be said that this technique is carried out from field data and then analyzed using relevant theories.

\section{RESULTS AND DISCUSSION}

\section{The Dual Role of Sirojul Ummah Person- nel}


Sirojul Ummah is a Marawis music group domiciled in Wado District, Sumedang Regency, West Java Province. This group consists of personnel who are mothers around the ages of 47 to 70 years. Apart from being housewives, these women work as sellers of home-processed food and work in the fields in their daily lives. They do this work, apart from helping their husbands increase their income for household needs, as well as an activity to spend their spare time. Likewise with musical activities, through Marawis, they can earn a little income from invitations to fill the event, and especially these activities become a medium of their interaction on religious values, namely gratitude to Allah SWT., and prayer to the Prophet Muhammad SAW., and social interaction in building good relationships with fellow humans.

This group was officially established on February 1, 2010, found to develop knowledge and practice understanding of sholawat through Marawis music. In language terms, sirojul means charisma or role model, while ummah means people who adhere to the Prophet Muhammad SAW's teachings. So, it can be said thatt the word Sirojul Ummah is a name that has meaning and hope. The meaning is the nature that describes the Prophet's charism for the people, and the hope is that this group can always convey the charism of the Prophet to the community, especially in Cilengkrang Village, Wado District, Sumedang Regency. Sirojul Ummah is supported by 10 personnel, one of which is a 57-year-old man who plays drums. At the same time, the other nine people are mothers with an average age of 60 years. One of the nine mothers is a mother whose age is the youngest among the others; 47 years old, and she is the vocalist of this group. What will be discussed in this section is the dual roles of women personnel of Sirojul Ummah. This attracted researchers' attention because they saw the interest and potential of these mothers in their efforts to develop creativity and musical skills.

Wibowo (2011), Dewi (2012), Patna- ni (2012), and Intan (2014) argue that the dual role of women concerns the role of tradition and transition. The role of tradition is the roles of Sirojul Ummah personnel as a wife, mother, and household manager. Meanwhile, the transitional role is women's role as members of society who have rights and obligations in social interaction and demonstrate their abilities in their respective fields. Both the role of tradition and the role of transition, for these mothers, do not become obstacles that affect each other's roles with other roles. According to them, the key to undergoing all of this is patience, awareness, and sincerity. However, the inevitable choice for them is the role of tradition, which means that the position in this role is higher than the role of transitional. On the other hand, the support of husbands and children to the mothers of Sirojul Ummah personnel is one aspect that fosters the spirit to perform and participate in spreading knowledge and understanding of Islam to the surrounding community through fun and entertaining ways.

Activities carried out by Sirojul Ummah personnel in carrying out their traditional roles can be seen from how mothers' roles in general. Namely, an example where a mother prepares meals for her husband and children, washes clothes, and the biological needs of husband and wife. Even these things are commonly done by Sirojul Ummah women and are not at all a burden on the roles of transition, especially in the activities of Marawis. One of the factors is, from the researcher's observations, it was obtained a description of the age of the children of the Sirojul Ummah personnel. We found that some of their children are in adolescence who have the maturity to think and act. And some of them are adults, some even have families and have children. So, at least this factor is one of the factors that alleviate traditional roles, where the opportunity to carry out the transition roles is quite a lot.

Interpreting Associative and Dissociative Processes through Music Process 
The associative and dissociative processes in Sirojul Ummah's social interactions are present as a result of the motivation to develop self-competence, which is based on creativity and musical skills. Both creativity development and skills development are carried out through practice routines. These activities become an associative medium, in which there are cooperative, accommodating, and assimilating behaviors to improve the ability to create music, improve techniques for singing lyrics and melodies, as well as techniques and patterns of playing instruments. Meanwhile, in terms of dissociation, both in-group and out-group, researchers tend not to find this, this is due to the factors of age and maturity, as well as the life experience of each personnel, which has an impact on self-maturity, as well as ways of thinking and acting to avoid conflict.

Referring to Soekanto's opinion (2017), this associative behavior has been instilled since childhood in the family environment and kinship groups, as Sirojul Ummah personnel still have kinship ties with one another. In addition to the existence of these family ties, the pleasant atmosphere during the practice and performances, as well as mutual respect for the skills of each personnel, develop into a habit which is a factor that supports association interaction.

During almost 10 years of journey in Marawis art activities, efforts to regenerate the Sirojul Ummah group were carried out in a flow, following the flow of time and the development of community interests. No invitation is forcing the next generation to join this group. Nevertheless, the attention and appreciation of the next generation towards this group, especially women, is shown through an interest in learning in an unstructured pattern. For example, once there was a community member, she was a woman who was still in school at the senior high school level, who participated in practice activities with Sirojul Ummah several times. Then because of her obligations at school that could not be abandoned, it made her not train with Sirojul Um- mah for a long time, so that she could focus more on his school activities. After a while, because there was free time, she wanted to take part in the practice again and would be accepted by Sirojul Ummah to return to her activities together again. Similar opportunities are also given to other young women who are interested in developing, not only in Islamic values but also in terms of playing Marawis music skills.

The motivations shown by external parties as above are the impact of consistency by carrying out routine practice, participating in recitation activities together, and performing at community thanksgiving events, to build learning in the surrounding community, especially children and young girls, both learning about the deepening of the verses and the aspects of the music, including learning about adab (proper behavior) in socializing.

The form of cooperation among Sirojul Ummah personnel in developing musical skills and creativity is built through practice processes. In the process, each person can exchange ideas and provide input to other personnel about developing techniques for playing musical instruments, developing playing patterns, and musical forms and structures. These developments are intended to provide variations on a song. This is done because, along with the development of a public appreciation for music, it requires Sirojul Ummah personnel to study and develop patterns, forms, and structures of Islamic songs that are popular or are currently popular, apart from songs with salawatan lyrics in Arabic.

The practice routine becomes an activity that accommodates each personnel in building solidarity in playing music. Although there is no individual conflict among personnel, conflicts can occur when learning new songs. That is the conflict when, for example, one of the Marawis instrument players does not yet understand the play of percussion patterns resulting from the development of arrangements, which of her lack of understanding can annoy other players. Usually one of the personnel will appear to accommo- 
date these obstacles. One way to do this is to do independent practice according to the tools being played. After being understood by the conflicted players, the practice was then continued at the joint practice stage. Soekanto (2017) believes that the accommodative process generates adaptive spirits, namely adjustment efforts in overcoming obstacles. Adjustment of the above case can be seen from each person's willingness to learn the complexities of several musical techniques with solutions, among others, through routine practice, or reducing musical complexity according to the ability of the players.

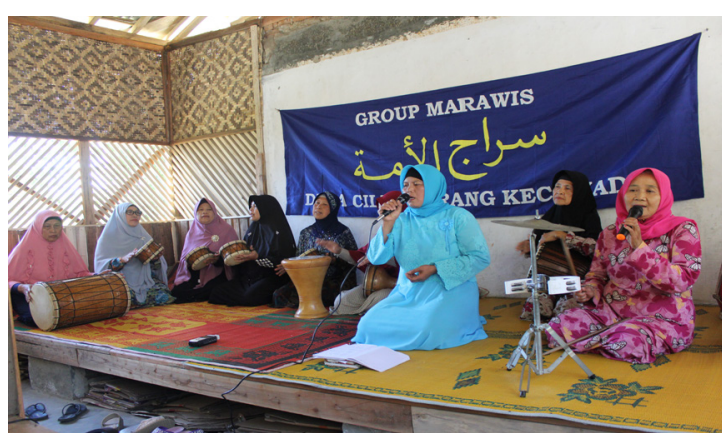

Figure 1. Routine practice activities of the Marawis music group Sirojul Ummah

When doing combined practices, accommodative methods are also applied. For example, to practice songs with a fast tempo, it is usually done in stages, from slow tempo first, then developed at fast tempo according to the original song's tempo. These accommodative methods are carried out to accommodate the differences in skills possessed by personnel. Even though this group has been founded for a long time, it does not mean that every time learning new material can be completed with just one practice. Because of the conflicts caused by musical aspects, the effort to accommodate them is by practicing repeatedly learning songs at other designated times.

In addition to the habit of working together and being accommodating in developing musical competences, the assimilation process in social interactions can be seen from personnel's efforts to identify themselves with the interests and goals of the group. This assimilation is a behavior in adapting to the circumstances that occur. So that the situation in question becomes self-awareness when personnel tries to improve their creativity and musical skills, thus, it can be said that the assimilation process is a space where each person understands each other about the work steps of developing and maintaining their musicality. However, it is undeniable that sometimes personal conflicts become an obstacle to the formation of assimilation, especially problems outside of musical activities.

\section{Social Actions in Musical Activities}

According to Ritzer (2012), social action is an individual action that has a meaning or subjective meaning for himself and is directed to others' actions. Individual actions directed at inanimate objects are not social acts. An action can be said to be a social action if the action is directed at another individual. Social actions are based on instrumental rationality, value rationality, effective action, and traditional action. Action can be an individual subjectivity behavior, influenced by situations, and directed at other people or other groups.

The instrument's rationality is a social action based on the goal in which the goal has a role as a means (instrument) that leads the actions taken. This action is carried out consciously by the individual in response to the conditions of space and time and can use supporting facilities. It can be said that, in the case of the musical process, musical instruments are used as a means of conveying musical ideas and thoughts to other people or other groups. However, these ideas and thoughts require processes in processing and developing musical aspects. Thus, if Sirojul Ummah aims to convey knowledge and understanding of Islamic values to the community, they use Marawis music to interact with other people or other groups (out-group). Meanwhile, it can be found from the ingroup side in practicing activities to develop and cultivate musical aspects.

In terms of value rationality, the me- 
ans used are conscious considerations in interacting, but interaction goals cannot be separated from individual values. When related to the activities of Sirojul Ummah, it can be said that religious values and musical values are in each of its personnel. Based on religious values, Sirojul Ummah strives to convey Allah's oneness (SWT) and stories of the example of the Prophet Muhammad SAW. to the community so that interaction is established, both ingroups and out-groups.

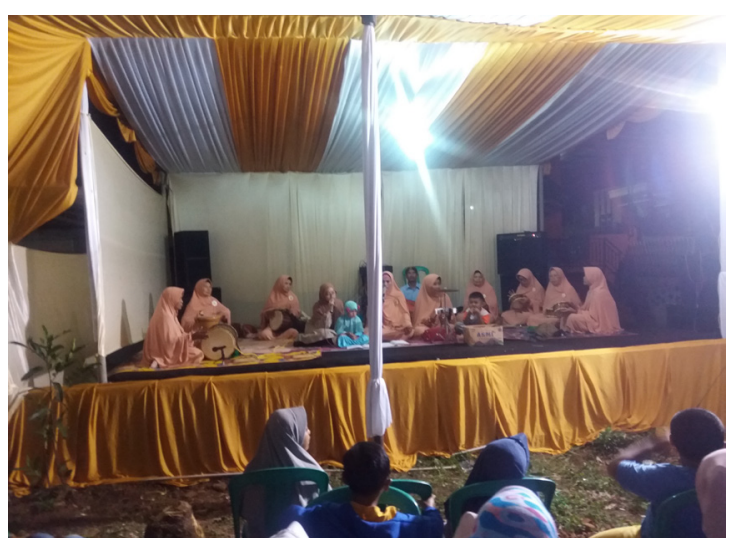

Figure 2. One of the activities of the Marawis music group Sirojul Ummah

In the activity of interacting with religious values to the community, one of the efforts made by Sirojul Ummah is to use Marawis music as a medium that accompanies their activities. As the opinion of Umar (2017), this is based on the view that the use of musical aspects is seen as effective in conveying religious messages to people because, in music, there is a process of processing taste. According to Dewantara (1967), the impressions that arise on feelings and temperament are deeper than knowledge because these impressions give satisfaction while knowledge does not.

The understanding of musical aspects possessed by Sirojul Ummah personnel is the result of a series of musical activities, both through practice activities and performance activities. The conditions in which each personnel help each other in increasing their abilities can be said as an act of affection. Referring to the definition, affection is a psychological category that exists because of feelings, enthusiasm, mentality, and emotions. Having affection in a person encourages him to take actions to achieve expectations by relying on the values they believe in. Thus, it can be said that the effective actions shown by Sirojul Ummah in social interaction are principally based on their hopes by relying on religious values and musical values. The hopes of Sirojul Ummah from relying on religious values are that they can interact with the public about Islamic values as Rahmatan Lil Alamin, whose foundation is Allah SWT's oneness the role model of Muhammad SAW., as the best human being. Meanwhile, musical values' hopes are sharpening of taste through creative efforts, supported by musical skills.

Regarding traditional actions, it can be said that the behaviors shown by the personnel of the Marawis music group Sirojul Ummah in social interactions are formed by their habits that have been embedded since they were young. They have gained an understanding of religion since childhood. However, the understanding of musicals was only obtained from the interaction among Sirojul Ummah personnel; then it developed over time due to the interactions of the personnel with the community outside the Sirojul Ummah group.

\section{CONCLUSION}

Age does not become a barrier for Sirojul Ummah personnel to develop creativity and skills in expressing musical ideas. Music's role is seen as necessary in interacting with the community so that this becomes the basis for them to routinely learn and practice to hone their musical taste, performance cohesiveness, and techniques for playing instruments and singing Islamic lyrics with harmonious melodies. Music is a medium in social interaction, but the music becomes a motivation for social interaction.

The social interactions carried out by members of the Sirojul Ummah music group are based on the act of instrument rationality, namely actions that are based 
on the goal of imparting knowledge of Islamic values, with the hope of developing an understanding of the rights and obligations as Muslims to society. As an effort to achieve goals and hopes, music is used as the medium. Therefore, it cannot be denied that musical values are both the subject and the object of interaction, both in-groups and out-groups in terms of associative and dissociative aspects.

The enthusiasm in achieving the group's goals and expectations and in interacting to develop musical aspects is a tangible manifestation of affective actions. Affective actions are formed because of traditional actions, namely actions that become part of the life process, then become habits for the personnel.

\section{REFERENCES}

Ahdiah, I. (2013). Peran-Peran Perempuan Dalam Masyarakat. Academia 5(2), 85-92.

Alwasilah, C. (2011). Pokoknya Kualitatif: Dasar-Dasar Merancang Dan Melakukan Penelitian Kualitatif. Jakarta: Pustaka Jaya.

Amalia, A. H \&. Asrinda. (2018). Makna Dan Simbol Dalam Proses Interaksi Sosial: Sebuah Tinjauan Komunikasi. Risalah, 29(1), 16-19.

Andjani, K. (2014). Apa Itu Musik? Kajian Tentang Sunyi Dan Bunyi Berdasarkan 4'33" Karya John Cage. Tangerang: CV Marjin Kiri.

Dewantara, K. H. (1967). Bagian II A - Kebudayaan. Yogyakarta: Majelis Luhur Persatuan Taman Siswa.

Dewi, P. M. (2012). Partisipasi Tenaga Kerja Perempuan Dalam Meningkatkan Pendapatan Keluarga. Jurnal Ekonomi Kuantitatif Terapan, 5(2), 119-24.

Djohan, K. \&. (2017). Musik Gamolan Untuk Menumbuhkan Relasi Sosial. Resital: Jurnal Seni Pertunjukan 18(3), 159-67.

Gilin, J. L. \&. John P. (1950). Cultural Sociology. New York: Macmillan.

Hogenson, M. Z. \&. Robert. (1987). Basic of Music. New York: Schirmer Books.
Intan, S. (2014). Kedudukan Perempuan Dalam Domestik Dan Publik Perspektif Jender (Suatu Analisis Berdasarkan Normatifisme Islam). Jurnal Politik Profetik, 3(1),1-16.

Nuqul, M. A. \&. Fathul Lubabin. 2017. Ungkapkan Rasamu: Pemberian Musik Perkusi Dalam Meningkatkan Ekspresi Emosi Anak Autis. Psikovidya 21(1),13-27.

Patnani, M. (2012). Kebahagiaan Pada Perempuan. Psikogenesis, (1), 56-64.

Patzold, U. U. (2011). Self Defense and Music in Muslim Contexts in West Java Dalam Devine Inspiration: Music and Islam in Indonesia. Edited by D. H. \& A. Rasmussen. New York: Oxford University Press.

Pradoko, S. (2019). Positive Paradigm as the Barrier of Art Creativity Interpretation. Harmonia: Journal of Arts Research and Education, 19(2), 133-40.

Ritzer, G. (2012). Teori Sosiologi: Dari Sosiologi Klasik Sampai Perkembangan Terakhir Postmodern. Yogyakarta: Pustaka Pelajar.

Santoso, S. (2010). Teori-Teori Psikologi Sosial. Bandung: PT Refika Aditama.

Seashore, C. E. (1967). Psychology of Music. New York: Dover Publications Inc.

Soekanto, S. (2017). Sosiologi Suatu Pengantar. Depok: Raja Grafindo.

Subandi. (2011). Deskripsi Kualitatif Sebagai Satu Metode Dalam Penelitian Pertunjukan. Harmonia: Journal of Arts Research and Education, 11(2),173-79.

Umar, N. (2019). Islam Dan Dunia Seni." Retrieved from (http://nasaruddinumar.org/islam-dan-duniaseni/\%3E).

Wibowo, D. E. (2011). Peran Ganda Perempuan Dalam Kesetaraan Gender. Muwazah 3(1), 354-64.

Wulan, W., Wadiyo \& Sunarto. (2016). Madihin Ar Rumi: Kreativitas Musik Dan Tindakan Sosial Dalam Penyajiannya. Catharsis, 5(2),107-13.

Wulansari, D. (2013). Sosiologi: Konsep Dan Teori. Bandung: PT Refika Aditama. 